\section{IJ§ER}

ISSN: 2149-5939
International Journal of Social Sciences and Education Research

Online, http://dergipark.gov.tr/ijsser

Volume: 3(1), 2017

\title{
Examining the effect of artificial wall climbing as a leisure time activity on undergraduate's problem-solving skills ${ }^{1}$
}

Güçlü Özen ${ }^{2}$

Received Date: 13 / 09 / 2016

\author{
Şerife Vatansever ${ }^{3}$
}

Accepted Date: 12 / 12 / 2016

\begin{abstract}
The main objective of the study is to determine the effects of university students' artificial climbing wall experiences, which is considered among experimental learning (learn by doing) activities and defined as "high activity", on their problem solving skill levels. Artificial wall climbing emerges as a learning point which is both a game as of its content and an activity providing people to be active, not passive, through experimental learning activities and creating people opportunities to know better about themselves and others as well as their limits. Pretestposttest control group experimental model was used in this study. Experiment group participated into the practice twice in a week, totally for eight weeks. During this time, the control group continued their normal daily routines and not joined any activity. To collect data, Problem Solving Inventory developed by Heppner and Peterson (1982) was used. As a result of statistical analysis, statistically significant differences ( $p<0.05)$ were found between subscales and total scores of hasty approach, confident approach and planned approach. Consequently, activities done during artificial wall climbing have been causing positive development in problem solving skills \& perception levels of university students.
\end{abstract}

Keywords: Problem solving skills, experimental learning, artificial wall climbing

\section{Introduction}

Individuals learn from their own lives, their own experiences and they can evaluate learning outcomes safely. The process based on learning of individuals from their own lives \& their own experiences and then evaluating the learning outcomes safely is called "experimental learning method (learn by doing)" (Kolb, 1984).

The whole activities that held in educational institutions providing participants to move out their comfort zone lead them to change by acting as a catalyzer which is designed for encouraging the participants to understand both themselves and others. One of the most effective tools used during this process is climbing wall which is among the artificially high activities used for moving participants out of their comfort zone (Kenzie, 2000). It has been indicated that such kind of activities provide a good opportunity both for personal development and socialization. Additionally, this experience will create opportunities for participants to explore their leadership characteristics as well as positively develop social patterns on their problem solving, communication, confidence, and locus of control abilities (Çelebi and Özen 2004).

${ }^{1}$ This work was supported and funded by the Scientific Research Projects Unit (2012.16.02.483) of the University of Abant Izzet Baysal

${ }^{2}$ Corresponding Author, Ass. Prof., School of Physical Education and Sports, Abant Izzet Baysal University, Bolu,

Turkey, guclu1234@yahoo.com

${ }^{3}$ Uludağ University, Faculty of Sports Science, Bursa, Turkey, serifevatansever@yahoo.com 
Özen, G., Vatansever, Ş. (2017). Examining the effect of artificial wall climbing as a leisure time activity on undergraduate's problem-solving skills. International Journal of Social Sciences and Education Research, 3(1), 39-48.

Experimental learning is based on a student-participant oriented learning process instead of a traditional teacher-trainer learning process and it should be a combination of experience, perception, cognition, and behavior. Even if most of the open-field and adventure programs focus on physical challenges in the natural environment, experimental learning is defined as a holistic method (Hopkins and Putnam, 1993).

In the penetrated pedagogical philosophy, the safety of all points including the existence of perceived risk has been achieved however personal control has brought forward that participants are able to choose to participate in which activity at which level that creates a safe and supportive group atmosphere (Neil, 2006).

Literature divides the achievements of such kinds of trainings basically into two categories: First is individual development and the second is group development. Mentioning about development on problem solving, socialization, development of self-confidence and locus of control etc. increases the importance of such kind of trainings (Dainty and Lucas 1992).

Individuals who have to make a decision against a problem or an experience can use various strategies such as relying on intuition, postponing decision-making, acting fatalistic, excessively thinking on a decision so wasting time, avoiding to take responsibility and risk on making a decision etc (Bowman, 1992). At this stage, individual differences and learned skills are engaged into the decision making process (Ferrari and Dovidio, 2001). Problem solving skills are also acquired throughout the development periods as an important social skills and personality characteristics, which closely affects the individual's social cohesion and daily-life success (Heppner and Anderson, 1985; Arenofsky, 2001). Problem solving is defined as a process requiring a number of efforts in order to eliminate the difficulties encountered for achieving certain goals whereas problem is a barrier against the existing power gathered by individuals to achieve a desired target (Bingham, 1998). According to Spence (2003), it is stated that effective problem solving individuals are able to think independently and creatively, have social competence and self-confidence that can tolerate uncertainties (Akt. Dow and Mayer, 2004).

Problem solving is a learnable characteristic (Heppner and Petersen). Individuals are obliged to use their cognitive, affective and behavioral capacities while trying to solve the problems faced in everyday life (Reis and Heppner, 1993).

Considering these facts, problems solving skills appear as a skill that needs to be focused on, developed and used various means and methods for its improvement. Artificial wall climbing done in our study also allows the demonstration of a sportive performance intensely with mental processes in a recreational activity, which slightly increases its importance.

\section{Method}

\subsection{Research Model}

In our study, it is aimed to determine the effect of artificial wall climbing activity, which is conceived by experimental learning, on problem solving skills. The study was designed in experimental design pattern including pretest and posttest control groups and Problem Solving Inventory was used to collect data.

Pre-test and post-test control group model are given in Table 1. 
Özen, G., Vatansever, Ş. (2017). Examining the effect of artificial wall climbing as a leisure time activity on undergraduate's problem-solving skills. International Journal of Social Sciences and Education Research, 3(1), 39-48.

Table 1. Pre-Test and Post-Test Control Group Model (Karasar, 1994)

\begin{tabular}{cccc}
\hline Groups & Pretest & Application & Posttest \\
\hline Experiment Group (G1) & R O1.1 & $\mathrm{X}$ & O1.2 \\
Control Group (G2) & R O2.1 & & O2.2 \\
\hline
\end{tabular}

\subsection{Sampling universe}

The study is the same as the sampling universe including 80 volunteer students ( 30 female, 50 male) studying at different faculties of our university (2012-2013 academic year). Participants were randomly divided into control and application groups.

Volunteer students in our study chosen in accordance with their weekday free time have participated into the study for two days (there was at least twenty four hours between these two days). Working time was organized as ninety minutes and it started with warm-up activities which is convenient for the age group. Then, it was configured in a development scheme which included appropriate routes for the age group with an overhead-safety extending to a development of the overhead-safety leadership climbing. During the application, not only the climbing skills but also it was ensured to acquire knowledge and skills on certain matters such as basic climbing techniques, basic knots, taking safety etc. and a survey was conducted before and after the eight-week studies.

\subsection{Data collection tools used in the study}

To collect data for our study, Problem Solving Inventory developed by P.P. Heppner and C.H. Peterson in 1982 and adapted into Turkish by N. Şahin, N.H Şahin and P.P Heppner in 1993 was used. This inventory is a scale, which is a kind of self-evaluation measuring the individual's perception on their problem solving skills. The inventory has been applied to adolescents and adults consisting of 35 items which was scored between 1-6 points as a Likerttype scale. The score range was between 32 and 192.

During the scoring period, $9,22,29^{\text {th }}$ items were excluded from scoring. Items numbered as $1,2,3,4,11,13,14,15,17,21,25,26,30$ and $34^{\text {th }}$ were scored as reverse. The score range was between 32 and 192. The highness of the total scores obtained from the scale shows that the individual perceives herself/himself insufficient on problem solving skills. In adaptation study, Cronbach's alpha internal consistency coefficient which was obtained for all inventory has been found 90, the coefficients that were obtained for the subscales have been found between 72 and 85 . In our study, Cronbach's alpha internal consistency coefficient has been found 88 for pretest and 91 for posttest. The coefficients obtained for the subscales have been found between 76 and 93 .

\section{Results}

Number of total participants in this study is $\mathrm{N}=80, \mathrm{~N}=50(\% 62,5)$ male, $\mathrm{N}=30(\% 37,5)$ female and the mean age was $20.02 \pm 2.52$. In order to compare pretest scores of control and experiment groups, $\mathrm{T}$ test was applied and the statistics were given in Table 1. 
Özen, G., Vatansever, Ş. (2017). Examining the effect of artificial wall climbing as a leisure time activity on undergraduate's problem-solving skills. International Journal of Social Sciences and Education Research, 3(1), 39-48.

Table1. "Locus of Control Scale" of experiment and control groups, Independent T-Test results for pre-test results

\begin{tabular}{|c|c|c|c|c|c|}
\hline & & $\bar{x}$ & SD & $t$ & $\mathrm{p}$ \\
\hline \multirow{2}{*}{ Hasty Approach } & Control & 26.27 & 3.36 & \multirow{2}{*}{1.07} & \multirow{2}{*}{.44} \\
\hline & Test & 25.65 & 3.14 & & \\
\hline \multirow{2}{*}{ Thinking Approach } & Control & 9.82 & 2.60 & \multirow{2}{*}{-1.32} & \multirow{2}{*}{.19} \\
\hline & Test & 10.24 & 2.17 & & \\
\hline \multirow{2}{*}{ Avoidant Approach } & Control & 8.96 & 1.21 & \multirow{2}{*}{.70} & \multirow{2}{*}{.17} \\
\hline & Test & 8.04 & 1.82 & & \\
\hline \multirow{2}{*}{ Evaluating Approach } & Control & 7.06 & 1.62 & \multirow{2}{*}{-.48} & \multirow{2}{*}{.63} \\
\hline & Test & 7.96 & 1.43 & & \\
\hline \multirow{2}{*}{ Self-Confident Approach } & Control & 19.43 & 3.11 & \multirow{2}{*}{1.24} & \multirow{2}{*}{.81} \\
\hline & Test & 18.79 & 3.05 & & \\
\hline \multirow{2}{*}{ Planned Approach } & Control & 9.71 & 1.30 & \multirow{2}{*}{.61} & \multirow{2}{*}{.54} \\
\hline & Test & 9.50 & 1.06 & & \\
\hline \multirow{2}{*}{ Problem Solving Total Score } & Control & 81.25 & 2.89 & \multirow{2}{*}{.87} & \multirow{2}{*}{.74} \\
\hline & Test & 80.18 & 326 & & \\
\hline
\end{tabular}
$* \mathrm{p}<\overline{0,05}$

Once examining pretest scores of test and control groups, there was no statistically significant difference $(p>0,05)$ found, which indicates that the group is homogeneous. For comparing pretest-posttest scores of the control group, dependent t-test was applied and statistics were given in Table 2 .

Table 2. Control Group Problem Solving Inventory, Pretest-posttest scores comparison table

\begin{tabular}{|c|c|c|c|c|c|}
\hline & & $\bar{x}$ & SD & $t$ & $\mathrm{p}$ \\
\hline \multirow{2}{*}{ Hasty Approach } & Pretest & 26.27 & 3.36 & \multirow{2}{*}{-1.83} & \multirow{2}{*}{.52} \\
\hline & Posttest & 27.01 & 2.74 & & \\
\hline \multirow{2}{*}{ Thinking Approach } & Pretest & 9.82 & 2.60 & \multirow{2}{*}{-.32} & \multirow{2}{*}{.62} \\
\hline & Posttest & 9.70 & 2.96 & & \\
\hline \multirow{2}{*}{ Avoidant Approach } & Pretest & 8.96 & 1.21 & \multirow{2}{*}{-.85} & \multirow{2}{*}{.43} \\
\hline & Posttest & 9.54 & 1.82 & & \\
\hline \multirow{2}{*}{ Evaluating Approach } & Pretest & 7.06 & 1.62 & \multirow{2}{*}{-.62} & \multirow{2}{*}{.75} \\
\hline & Posttest & 7.73 & 1.43 & & \\
\hline \multirow{2}{*}{ Self-Confident Approach } & Pretest & 19.43 & 3.11 & \multirow{2}{*}{.99} & \multirow{2}{*}{.46} \\
\hline & Posttest & 19.21 & 3.05 & & \\
\hline \multirow{2}{*}{ Planned Approach } & Pretest & 9.71 & 1.30 & \multirow{2}{*}{1.01} & \multirow{2}{*}{.63} \\
\hline & Posttest & 8.04 & 1.06 & & \\
\hline \multirow{2}{*}{ Problem Solving Total Score } & Pretest & 81.25 & 2.89 & \multirow{2}{*}{-1.17} & \multirow{2}{*}{.98} \\
\hline & Posttest & 81.23 & 3.26 & & \\
\hline
\end{tabular}

For comparing pretest-posttest scores of the test group, dependent t-test was applied and statistics were given in Table 3 . 
Özen, G., Vatansever, Ş. (2017). Examining the effect of artificial wall climbing as a leisure time activity on undergraduate's problem-solving skills. International Journal of Social Sciences and Education Research, 3(1), 39-48.

Table 3. Test Group Problem Solving Inventory, Pretest-posttest scores comparison table

\begin{tabular}{|c|c|c|c|c|c|}
\hline & & $\bar{x}$ & SD & t & $\mathrm{p}$ \\
\hline \multirow{2}{*}{ Hasty Approach } & Pretest & 25.65 & 3.14 & \multirow{2}{*}{4.83} & \multirow{2}{*}{$.04 *$} \\
\hline & Posttest & 23.01 & 2.74 & & \\
\hline \multirow{2}{*}{ Thinking Approach } & Pretest & 10.24 & 2.60 & \multirow{2}{*}{1.96} & \multirow{2}{*}{.62} \\
\hline & Posttest & 9.78 & 2.96 & & \\
\hline \multirow{2}{*}{ Avoidant Approach } & Pretest & 8.04 & 1.21 & \multirow{2}{*}{-.34} & \multirow{2}{*}{.53} \\
\hline & Posttest & 8.14 & 1.82 & & \\
\hline \multirow{2}{*}{ Evaluating Approach } & Pretest & 7.96 & 1.62 & \multirow{2}{*}{.62} & \multirow{2}{*}{.97} \\
\hline & Posttest & 6.23 & 1.43 & & \\
\hline \multirow{2}{*}{ Self-Confident Approach } & Pretest & 18.79 & 3.11 & \multirow{2}{*}{3.99} & \multirow{2}{*}{$.03 *$} \\
\hline & Posttest & 16.21 & 3.05 & & \\
\hline \multirow{2}{*}{ Planned Approach } & Pretest & 9.50 & 1.30 & \multirow{2}{*}{3.01} & \multirow{2}{*}{$.03 *$} \\
\hline & Posttest & 7.04 & 1.06 & & \\
\hline \multirow{2}{*}{ Problem Solving Total Score } & Pretest & 80.18 & 2.89 & \multirow{2}{*}{-6.17} & \multirow{2}{*}{$.00 *$} \\
\hline & Posttest & 70.41 & 3.26 & & \\
\hline
\end{tabular}

$* \mathrm{p}<0.05$

Once examining pretest-posttest scores, there was no statistically significant difference found between the subscales of control groups and total scores ( $p>0,05)$. However, in test group scores, there was a significant difference found between hasty approach, self-confident approach, planned approach subscales and total scores $(\mathrm{p}<0,05)$. These results (Table 2, Table 3) strengthen the fact that the point increase in problem solving skills perception level has been derived from the training program applied.

In terms of gender variable, Mann- Whitney U Test was applied to find the difference between test group pretest-posttest and the scores of difference of differences. The results were given in Table 4.

Table 4- Mann-Whitney U Test Table for examining Test Group Problem Solving Inventory scores in terms of gender variable

\begin{tabular}{|c|c|c|c|c|c|c|c|}
\hline & & \multicolumn{2}{|c|}{$\bar{x}$} & \multirow{2}{*}{\multicolumn{2}{|c|}{$\begin{array}{c}\text { SD } \\
\text { Male Female }\end{array}$}} & \multirow[t]{2}{*}{$\mathrm{Z}$} & \multirow[t]{2}{*}{$\mathrm{P}$} \\
\hline & & Male & Female & & & & \\
\hline \multirow{3}{*}{$\begin{array}{l}\text { Hasty Ap- } \\
\text { proach }\end{array}$} & Pretest & 25.15 & 26.04 & 3.56 & 3.41 & -1.04 & .75 \\
\hline & Posttest & 25.01 & 25.89 & 2.92 & 2.92 & .30 & .63 \\
\hline & Difference of Differences & & & & & .79 & .36 \\
\hline \multirow{3}{*}{$\begin{array}{l}\text { Thinking } \\
\text { Approach }\end{array}$} & Pretest & 9.54 & 8.99 & 2.07 & 2.46 & 1.15 & .69 \\
\hline & Posttest & 9.45 & 9.12 & 2.62 & 3.21 & .88 & .98 \\
\hline & Difference of Differences & & & & & .92 & .81 \\
\hline \multirow{3}{*}{$\begin{array}{l}\text { Avoidant } \\
\text { Approach }\end{array}$} & Pretest & 8.76 & 8.29 & 1.39 & 1.96 & .86 & .43 \\
\hline & Posttest & 9.04 & 8.84 & 2.09 & 2.09 & .76 & .98 \\
\hline & Difference of Differences & & & & & .71 & .57 \\
\hline \multirow{3}{*}{$\begin{array}{l}\text { Evaluating } \\
\text { Approach }\end{array}$} & Pretest & 7.39 & 7.46 & 1.89 & 1.19 & .92 & .75 \\
\hline & Posttest & 7.99 & 7.80 & 2.18 & 2.30 & .54 & .46 \\
\hline & Difference of Differences & & & & & .66 & .87 \\
\hline \multirow{3}{*}{$\begin{array}{l}\text { Self-Con- } \\
\text { fident Ap- } \\
\text { proach }\end{array}$} & Pretest & 19.07 & 18.85 & 3.98 & 3.64 & .65 & .68 \\
\hline & Posttest & 19.79 & 19.10 & 3.39 & 3.31 & .87 & .37 \\
\hline & Difference of Differences & & & & & .69 & .46 \\
\hline \multirow{3}{*}{$\begin{array}{l}\text { Planned } \\
\text { Approach }\end{array}$} & Pretest & 9.36 & 8.91 & 2.07 & 2.45 & 1.12 & .75 \\
\hline & Posttest & 8.61 & 8.70 & 1.96 & 2.19 & .89 & .63 \\
\hline & Difference of Differences & & & & & .93 & .94 \\
\hline Problem & Pretest & 81.25 & 78.54 & 2.16 & 2.35 & 1.02 & .71 \\
\hline Solving & Posttest & 81.23 & 79.45 & 3.22 & 2.97 & .85 & .89 \\
\hline Total & Difference of Differences & & & & & .95 & .49 \\
\hline Score & & & & & & & \\
\hline
\end{tabular}

$* \mathrm{p}<0,05$ 
Özen, G., Vatansever, Ş. (2017). Examining the effect of artificial wall climbing as a leisure time activity on undergraduate's problem-solving skills. International Journal of Social Sciences and Education Research, 3(1), 39-48.

In terms of gender variable, there was no statistically significant difference found between pretest-posttest and the scores of difference of differences ( $p>0,05)$, which indicates that the gender argument has no effect on educational acquisition.

\section{Discussion}

In this study, the effect of artificial wall climbing activities on problem solving skills. As for the results of this study, it was found that students participated into artificial wall climbing activities show a positive development in subscales of hasty approach, self confident approach, planned approach and total scores.

It is believed that one-to-one participation of climbing activities held throughout this study creates the opportunity for the participant to be active in his/her own learning process and internalize what he/she has learned (Rubin and Herbert, 1998). It has also been reported that such kind of activities move participants out of their comfort zone within the framework of perceived risk and provide personal development by feeding qualities such as cooperation, perseverance, determination, persistence, resistance, problem solving etc (Çelebi and Özen, 2004; Sheard and Golby, 2006) as well as provide competences such as perseverance of struggling etc. that can be used in real life (Neill, 2007). Considering this information, it is possible to say that the applied climbing program has leaded to positive development in problem solving skills perception of participants.

Climbing process which initially seems quite difficult or impossible but is achieved or can be achieved after many attempts over time could have brought a perspective to the participants that they are able to solve the encountered problems by using their inner strength and look for the reasons of events not in external sources but in their own efforts.

Additionally, it is considered that the sense of success or possibility to success emerged overtime provide individuals confronting with their problems, make various plan to try different ways in order to solve their problems instead of escaping from the problems encountered and ignoring problems by making instantaneous decisions. In the meta-analysis study conducted by Hans (2000), it has been highlighted that development focusing on locus of control is positive. In his study which examines the working principles of open field training Kenzie (2000) has reported that the participants show development on certain issues such as selfefficacy, self confidence, locus of control etc. In the light of this information, it is believed that the participants will perceive themselves better at subscales of self-confident approach, hasty approach and planned approach thanks to the aforementioned personal development emerged through the activities carried out in this study.

Throughout the activity process, the participants had the opportunity to work in groups formed by peers and studies highlighted that children in collaboration with peers have achieved better outcomes than the ones who study individually (Samaha and DeLisi, 2000, Underwood, Underwood and Wood, 2000). Similarly, it is indicated that the bond of reciprocity which is developed slowly in the group plays an important role for personal development of group members in open field training activities (Hopkins and Putnam, 1993). It is considered that a communication within the group members who are in their age group and in a positive group atmosphere created by trainers with high participating motivation and good 
Özen, G., Vatansever, Ş. (2017). Examining the effect of artificial wall climbing as a leisure time activity on undergraduate's problem-solving skills. International Journal of Social Sciences and Education Research, 3(1), 39-48.

problem solving skills provides participants get benefits from program outcomes at maximum level.

It is stated that experimental learning activities in which individuals participate actively play an important role personal development of the participants (Hattie et al., 1997; Breheney, 2000; Autry, 2001; Bartley, 2003; Çelebi and Özen, 2004; Gillis and Speelman, 2008; Özen et al., 2010). In literature, it is specified that various experiences such as rock climbing, canoe, camp activities etc feed certain qualifications like entrepreneurship, cooperation, perseverance, determination, persistence, resistance, problem solving etc. (Çelebi and Özen, 2004; Sheard and Golby, 2006). Considering all this information, it is possible to say that artificial wall climbing activity carried out in our study begets a positive development on participants' problem solving perception.

According to the findings of this study, the gender argument doesn't have a statistically significant effect on program outcomes. In the current literature, there are confusing findings in terms of problem solving skills and gender variable. Some researches (Koray and Azar, 2008; Korkut, 2002; D'zurilla et al., 1998; Pajares and Miller, 1994; Basmacı, 1998; Çam, 1996; Taylan, 1990) underline that male adolescents perceive themselves as a better problem solver than females whereas some researches (Cenkseven and Akar - Vural 2006) indicate that female adolescents have a better problem solving skills than male ones. In some other researches, it is stated that problem solving skills doesn't differentiate in terms of genders (Hoffman and Schraw, 2009; Otacioğlu, 2008; Hoffman and Spatariu, 2008; Köstereloğlu, 2007; Altunçekiç, Yaman and Koray, 2005; Saracaloğlu, Serin and Bozkurt 2001; Tümkaya and Ifflazoğlu, 2000). Heppner et al. (2004) have pointed out that the relationship between problem solving and gender hasn't been sufficiently clarified yet.

In terms of open field trainings, Hattie et al. (1997) states that the meta-analysis study which was carried out to examine the acquisitions of participants who joined trainings based on experimental learning formed by adventure-based activities has indicated that demographic characteristics, except advanced age level, are not highly effective on program achievements. Again on similar programs, Neil and Richards (1998) in their meta-analysis study have emphasized the significant effect of program duration on educational achievements whereas gender difference has no effect on it.

Hsieh (2007) who tried modeling the reasons for participating into adventure recreation activities has reported that the difference of gender, age and skill level affects the adventure quest however; certain variables such as gender, age and educational status don't affect the motivation of attendance.

Özen et al. (2010) have determined the positive effect of open field trainings on problem solving skills whereas they have reported that gender variable has no influence on this positive effect.

\section{Result}

Consequently, it is possible to say that artificial wall climbing activity which is based on experimental learning has a positive effect on participants' level of problem solving skills. 
Özen, G., Vatansever, Ş. (2017). Examining the effect of artificial wall climbing as a leisure time activity on undergraduate's problem-solving skills. International Journal of Social Sciences and Education Research, 3(1), 39-48.

Considering the fact that the individual's existing competencies cannot only be the result of his/her own ability and effort but can also be the result of social-economic and cultural opportunities that the individual has (Ekinci, 2011), higher education programs should submit different opportunities to the students. In this case, the road for students to participate into more diverse and numerous activities will be opened, which is quite important to grow up individuals who are more confident, socially self-sufficient with high problem solving skills.

\section{References}

Altunçekiç, A., Yaman. S. ve Koray. Ö. (2005) A Study on Determining the Self-efficacy Belief Levels of Social Studies Teacher Candidates (Example of Kastamonu Province ). Kastamonu Journal of Education, 13 (1), 93-102.

Arenofsky, J. (2001). Developing your problem-solving skills. Career World, 29(4): 18-21.

Autry, C.E. (2001). Adventure therapy with girls at risk: Responses to outdoor experiential activities. Therapeutic Recreation journal, 35(4), 289-306.

Bartley, S.J., Kupritz, V.W., Powers, M. (2003), Effectiveness of a low ropes course experience to promote learning in an HRD graduate course. Workforce Education Forum 30(1), 22-37.

Basmac1, S. K. (1998). Investıgatıng Perception Of Problem Solvıng Skılls Of University Students In Terms Of Some Variables. Inonu University Institute of Social Sciences. Unpublished MS Thesis. Malatya

Bingham, A. (1983). Çocuklarda Problem Çözme Yeteneklerinin Gelistirilmesi.(Çev: A. Ferhan OGUZKAN). 6stanbul: MEB Basimevi

Bowman, S.Y. (1992). Decision making styles of a medical center's management group: A case study. Hospital Topics, 70 (3), 25-30.

Breheny, M. S. (2000). Investigating The Effects Of A Low Ropes Course Experience Vs. Classroom Instruction On The Problem-Solving Appraisal of college Freshmen. Dissertation Abstracts International, 61(05A), 1738. (UMI No. AAI9976182)

Çam, S., (1996). Effect of Education of Communication Skills Training Program on Teacher Candidates' Ego State and Problem Solving Skills Perception, Unpublished Phd Thesis, Ankara University Institute of Social Sciences, Ankara.

Celebi, M., Ozen, G. (2004, March). University students and adventure education programmes: A study of meanings and experience of adventure training activities. In W. Krause (Ghair), Outdoor and adventure education - developments and programmes. Symposium conducted at the meeting of the International Gonference on Leisure, Tourism \& Sport-Education,Integration, Innovation, Gologne, Germany.

Cenkseven, F., Akar-Vural, R. (2006) A comparison of problem-solving skills based on the perceived needs of thinking and gender adolescents, Journal of Educational Research, 25, 45-53.

D’Zurilla, T.J., Chang, E.C., Nottingham, E.J., Faccini, L. (1998). Social problem solving deficits and hopelessness, depression, and suicidal risk in college students and psychiatric inpatients. Journal Of Clinical Psychology, 54 (8), 1091-1107.

Dainty, P., Lucas, D. (1992). Clarifying the confusion: A practical framework for evaluating outdoor development programmes for managers. Lancaster: Management Education and Development.

Dow, G. T., Mayer, R. E., (2004). Teaching Students to Solve İnsight Problems: Evidence for Domain Specificity in Creativity Training, Creativity Research Journal, Vol. 16( 4), 389-402 
Özen, G., Vatansever, Ş. (2017). Examining the effect of artificial wall climbing as a leisure time activity on undergraduate's problem-solving skills. International Journal of Social Sciences and Education Research, 3(1), 39-48.

Ekinci, C. E, (2011). Impact of Some Socio-economic Factors on Higher Education Participation in Turkey, Education and Science, 36 (160), 281-297

Ferrari, J.R., Dovidio, J.F. (2001). Behavioral information search by indecisives. Personality and Individual Differences, 30, 1113-1123.

Gillis, H. L., Speelman, E. (2008). Are challenge (ropes) courses an effective tool? A meta-analysis. Journal of Experiential Education, 31(2), 111-135.

Hans, T. (2000). A meta-analysis of the effects of adventure programming on locus of control. Journal of Contemporary Psychotherapy, 30 (1), 33-60.

Hattie, J., Marsh, H. W., Neill, J. T., Richards, G.E., (1997). Adventure education and Outward Bound: Out-of-class experiences that make a lasting difference. Review of Educational Research, 67, 4387.

Heppner, P.P., Anderson, W.P. (1985). The relationship between problem solving self-appraisal and psychological adjustment. Cognitive Therapy and Research, 4, 415-427.

Heppner, P.P., Witty, T.E. Dixon,W. A. (2004). Problem-solving appraisal and human adjustment: Are view of 20 years of research using the Problem Solving Inventory. The Counseling Psychologist, 32 (3), 344-428

Hoffman, B., Schraw, G. (2009). The influence of self-efficacy and working memory capacity on problem-solving efficiency. Learning and Individual Differences, 19, 91-100.

Hoffman, B., Spatariu, A. (2008). The influence of self-efficacy and metacognitive prompting on math problem-solving efficiency. Contemporary Educational Psychology, 33, 875-893.

Hopkins, D., Putnam, R. (1993). Personal growth through adventure. London: David Fulton.

Hsieh, T.C. (2007). Recreational motivation, sensation seeking, and recreational involvement of Taiwan's adventure recreation participants by, Ph.D., University of the Incarnate Word, AAT 3255770 http://proquest.umi.com/pqdlinkdid=1303296031\&Fmt=7\&clien$\mathrm{tId}=46571 \& \mathrm{RQT}=309 \& \mathrm{VName}=\mathrm{PQD} \& \mathrm{cfc}=1$

James T. Neill (Editor), Ozgur Akbas, Crystal Chalich, Ben Clapp, Andrew Coppens, Sara Decker, Taras Ferencevych, Jeff Heyliger, Brian Nelson, Kristy Putnam, \& Norm Staunton, University of New Hampshire, 2003 update 17 May 2006 http://www.wilderdom.com/projectadventure/pabibliography.htm

Karasar, N. (2005). Scientific Research Methods: Concepts, Principles and Techniques., Ankara: Nobel Publishing

Kenzie, M. (2000)., How are Adventure Education Program Outcomes Achieved?: A review of the literature, Australian Journal of Outdoor Education, 5(1), 19-28

Kolb, D.A., (1984). Experiential Learning: Experience as the Source of Learning and Development. New Jersey: Prentice Hall, Inc.

Koray, Ö., Azar, A. (2008). An Analysıs Of High School Students' Problem Solving And Logical Thınkıng Abilities In Terms Of Gender And Preferred Field. Kastamonu Education Journal, 16 (1), $125-136$.

Korkut, F. (2002). Problem Solving Skılls Of High School Students. H. U. Journal of Education, 22, $177-184$. 
Özen, G., Vatansever, Ş. (2017). Examining the effect of artificial wall climbing as a leisure time activity on undergraduate's problem-solving skills. International Journal of Social Sciences and Education Research, 3(1), 39-48.

Köstereloğlu, M. A. (2007). The Relationship Between Problem-Solving Skills And Burnout Levels of School Administrators. Unpublished MS Thesis, Abant Izzet Baysal University Institute of Social Sciences, Bolu.

Kuralbaeva, A., Orazkhan, N., Mamatoglu, N. (2014) The Usage Of The Innovative Pedagogical Technology In The Process of Teaching Mathematics For Primary School Pupils, Life Science Journal, 11(3), 17-22

Neill, T., Richards, G.E. (1998). Does outdoor education really work? A summary of recent meta analyses, Australian Journal of Outdoor Education, 3, 2-9.

Otacıoğlu, S. G. (2008). The Relatıons Between The Musıc Department Undergraduates' Levels Of Problem Solving, Self Esteem And Their Successes In Playıng Instruments. Journal Of Ahmet Keleşoğlu Education Faculty, 26, 143-154

Özen G., Yalçin H.B., Özen S. (2010) The Impact Of Adventure Based Educatıon On Problem Solvıng Ability, 11th International Sports Sciences Congress, Antalya

Pajares, F., Miller, M. D. (1994). Role of self-efficacy and self-concept beliefs in mathematical problem solving: A path analysis. Journal of Educational Psychology, 86 (2), 193-203.

Rubin, L., Hebert, C. (1998). "Model for Active Learning: Colaborative Pear Teaching, College Teaching, 46, 26-30

Samaha, N. V., DeLisi, R. (2000) Peer collaboration on a nonverbal reasoning task by urban minority students, Journal of Experimental Education, 69(1), 5-14

Saracaloğlu, A. S., Serin, O., Bozkurt, N. (2001). The Relatıonshıp Between The Problem Solvıng Skılls And The Achievement of Graduate Students of The Graduate School of Educational Sciences. M. Ü. Atatürk Education Faculty Journal of Educational Sciences, 14, 121-134.

Sheard, M., Golby. J. (2006). Efficacy of an out-door education curriculum on selected aspects of positive psychological development. Journal of Experiential Education, 29 (2), 87-209.

Tümkaya, S., İflazoğlu, A. (2000). C.U. Examination of classroom teaching students on the level of automatic thinking and problem solving, according to some socio-demographic variables, Ç. U. Journal of the Institute of Social Sciences. 6 (6), 143-158.

Underwood, J. Underwood, G. Wood, D.(2000) When does gender matter? Interactions during computer-based problem solving, Learning and Instruction, 10(5), 447-462

\section{Acknowledgement}

This work was supported and funded by the Scientific Research Projects Unit (2012.16.02.483) of the University of Abant Izzet Baysal. The authors thank the institution which collaborated and supported this research and all the participants for their participation in this study. 